JH lus Quia lustum is licensed under a Creative Commons Attribution 4.0 International License. Which Permits unrestricted use, distrubution, and reproduction in any medium. provided the original work is properly cited

\title{
Kebijakan Hukum Vrijwillige Orderwepping Dan Toepasselijk Verklaring Sebagai Unifikasi Pemerintah Hindia Belanda
}

\author{
Entol Zaenal Muttaqin dan Ahmad Zaini \\ Fakultas Syariah UIN SMH Banten Indonesia \\ Jln. Jendral Sudirman No. 30 Serang-Banten 42121 Indonesia \\ zaenal.muttaqin@uinbanten.ac.id; ahmad.zaini@uinbanten.ac.id
}

Received: 22 September 2020; Accepted: 21 Juli 2021; Published: 25 Agustus 2021

DOI: 10.20885 /iustum.vol28.iss3.art10

\begin{abstract}
This paper aims firstly, to identify the background of how the Vrijwillige Onderwepping and Toepasselijk Verklaring policies are made. Second, to explore the influence of the policies of Vrijwillige Onderwepping and Toepasselijk Verklaring in realizing legal unification in the Dutch East Indies. The method used is normative juridical with statutory and historical approaches. At the end this paper concludes that, First, the vrijwillige onderwepping and toepasselijk verklaring policies were made to bridge two different perspectives even though the ultimate goal is unification. Second, this policy greatly influenced the submission of the natives to European law although complete unification was never achieved due to the arrival of the Japan in 1942.
\end{abstract}

Key Words: Dualism of the law; toepasselijk verklaring; unification; vrijwillige onderwepping

\section{Abstrak}

Tulisan ini memiliki tujuan, pertama, mengetahui latar belakang kebijakan Vrijwillige Onderwepping dan Toepasselijk Verklaring dibuat. Kedua, mendalami pengaruh kebijakan Vrijwillige Onderwepping dan Toepasselijk Verklaring dalam mewujudkan unifikasi hukum di Hindia Belanda. Metode yang digunakan adalah yuridis normatif dengan pendekatan peraturan perundang-undangan dan historis. Pada akhir paragraf tulisan ini menyimpulkan bahwa, Pertama, kebijakan vrijwillige onderwepping dan toepasselijk verklaring dibuat untuk menjembatani dua perspektif yang berbeda meskipun tujun akhirnya adalah unifikasi. Kedua, kebijakan ini sangat berpengaruh terhadap penundukan pribumi kepada hukum Eropa meskipun unifikasi utuh tidak pernah tercapai karena kedatangan Jepang pada tahun 1942.

Kata-kata Kunci: Vrijwillige onderwepping; toepasselijk verklaring; unifikasi; dualisme hukum 


\section{Pendahuluan}

Sebagai bekas negara koloni penjajah Belanda, Indonesia (dahulu Hindia Belanda) memiliki warisan sistem hukum yang identik dengan karakteristik model hukum Eropa Kontitental, sejak pemerintah kerajaan Belanda mengambil alih kekuasaan Hindia Belanda dari tangan VOC (Vereenigde Oostindische Compagnie) di paruh abad 18 pola kekuasaan berubah secara signifikan. ${ }^{1}$ Pemerintah kolonial Belanda secara bertahap mulai menerapkan sistem hukum secara sistematis sebagai bagian dari daerah kekuasaannya, dan dengan demikian politik hukum sebagai arah kebijakan hukum sudah berlangsung.

Usaha penerapan sistem hukum di Hindia Belanda pada dasarnya pernah dilakukan oleh VOC dengan mencoba mengklasifikasikan hukum sesuai dengan karakteristik hukum lokal (hukum adat) yang terbagi dalam empat kategori, ${ }^{2}$ yaitu Compendium Mogharraer (kodifikasi hukum pidana jawa), Compendium Clootwijk (Hukum Adat di Bone dan Goa), Compendium Freijer (Kodifikasi hukum Islam dalam perkawinan dan talak), Pepakem Cirebon (Hukum adat Cirebon).

Usaha pengklasifikasian hukum tersebut berlanjut ketika kekuasaan berada pada pemerintah kolonial Belanda, dan Usaha saat itu masih serupa, mengkodifikasi dan mengklasifikasikan hukum yang hidup di Hindia Belanda. Tatkala perubahan konstitusi di negeri Belanda berlangsung di tahun 1848, maka kebijakan politik hukum di hindia Belanda pun turut berubah, dan salah satu kebijakannya juga terkait dengan arah politik hukum Islam sebagai hukum yang dianut oleh sebagian masyarakat pribumi di Hindia Belanda.

Kebijakan pemerintah untuk menyeragamkan kebijakan hukum dan politik sebagaimana yang terjadi di negeri Belanda menuai konflik di kalangan para birokrat dan ilmuwan di Hindia Belanda, sehingga menimbulkan ketidaksepahaman paradigma politik hukum, terutama terhadap Islam. Para birokrat menginginkan sebuah unifikasi hukum secara utuh, sedangkan kalangan ilmuwan berkehendak adanya pembedaan sistem hukum dikalangan pribumi dan non pribumi atau dualisme hukum. Perbedaan pendapat juga terjadi di kalangan ilmuwan seperti yang terjadi antara L.W.C van Den Berg yang

1 J.S Furnivall, Studies in The Social and Economic Development of The Netherlands East Indies IIb, An Introduction to The History of the Netherlands India, 1602-1836, Cambridge University Press, Cambridge, 2010, hlm. 16.

${ }^{2}$ Muhammad Bushar, Pengantar Hukum Adat, Pradnya Paramitah, Jakarta, 1983, hlm. 57. 
mengeluarkan teori Receptie in Complexu yang menyatakan bahwa hukum adat adalah hukum yang telah diresepsi oleh hukum Agama (1847-1878), ${ }^{3}$ dan van Vollenhoven menolaknya secara tegas dengan teori receptie in contrario yang menyatakan bahwa hukum adat yang ada di Hindia Belanda bukan berasal dari Hukum Islam, tetapi dari peradaban Melayu Polinesia yang ditambah dengan unsur-unsur agama yang juga berarti hukum Islam bersifat subordinat. ${ }^{4}$

Terlepas dari perdebatan unifikasi dan dualisme sistem hukum, pemerintah akhirnya menerapkan dualisme sistem hukum semu. Dualisme hukum semu membiarkan dua sistem hukum yang ada, yaitu hukum Belanda dan hukum pribumi yang dalam hal ini termasuk di dalamnya adalah Islam. Pemberlakuan ini bukan semata-mata karena Belanda menghargai atau mentoleransi sistem hukum di luar miliknya, tetapi sebagai sebuah strategi dan politik hukum agar kelak dikemudian hari dapat mudah dilakukan unifikasi. Dualisme semua ini kemudian terlaksana melalui kebijakan konkrit Vrijwillige onderwepping (penundukan sukarela) dan Toepasselijk Verklaring (kebijakan aturan memaksa). Dua kebijakan ini perlahan-lahan akan menjadikan hukum adat yang ada di Hindia Belanda akan hilang.

Berangkat dari manuver pemerintah mengeluarkan dua kebijakan tadi, maka terdapat perubahan tatanan arah politik hukum di masa akhir kekuasaan pemerintah kolonial, karenanya hal ini pula yang kemudian merubah secara signifikan aturan-aturan hukum yang berlaku, khususnya bagi pribumi. Berdasarkan fenomena di atas, tulisan ini bermaksud untuk menganalisa secara mendalam mengenai apa latar belakang kebijakan hukum Vrijwillige onderwepping dan Toepasselijk Verklaring dalam konteks politik hukum unifikasi, serta untuk melihat seberapa berpengaruh dua kebijakan tersebut dalam proses unifikasi hukum di Hindia Belanda.

\section{Rumusan Masalah}

Berangkat dari pendahuluan yang telah dijelaskan di atas, maka rumusan masalah yang hendak di jawab dalam tulisan ini, sebagai berikut. Pertama, bagaimanakah latar belakang kebijakan Vrijwillige Onderwepping dan Toepasselijk

\footnotetext{
${ }^{3}$ Soerjono Soekanto, Meninjau Hukum Adat Indonesia, Rajawali, Jakarta, 1981, hlm. 66

${ }^{4}$ Ibid., hlm. 69-70
} 
Verklaring dibuat? Kedua, bagaimanakah pengaruh kebijakan Vrijwillige Onderwepping dan Toepasselijk Verklaring dalam mewujudkan unifikasi hukum di Hindia Belanda?

\section{Tujuan Penelitian}

Berdasarkan rumusan masalah yang dijabarkan di atas, maka tulisan ini memiliki tujuan, sebagai berikut: pertama, mengetahui latar belakang kebijakan Vrijwillige Onderwepping dan Toepasselijk Verklaring dibuat. Kedua, mendalami pengaruh kebijakan Vrijwillige Onderwepping dan Toepasselijk Verklaring dalam mewujudkan unifikasi hukum di Hindia Belanda.

\section{Metode Penelitian}

Penelitian termasuk penelitian yuridis normatif yang bersifat deskriptif. Dikatakan deskriptif karena hendak menggambarkan secara jelas dan seteliti mungkin, ${ }^{5}$ dengan menggunakan pendekatan peraturan perundang-undangan dan historis, yaitu mengkaji kaidah kaidah hukum baik secara formal maupun materil berbagai peraturan perundang-undangan, ${ }^{6}$ terutama yang terkait dengan kebijakan pemberlakuan dualisme hukum di masa kolonial Hindia Belanda.

\section{Hasil Penelitian dan Pembahasan}

\section{Sistem Hukum Setelah Peralihan Kekuasaan Kepada Kerajaan Belanda}

Pada masa VOC berkuasa di Hindia Belanda antara 1600 sampai dengan 1800, terdapat banyak usaha untuk mengumpulkan dan mengkodifikasikan tatanan hukum yang hidup di nusantara saat itu, maka beberapa usaha mengumpulkan tatanan hukum tersebut terjadi, antara lain yang dilakukan oleh Rijckloff van Goens (1619-1682), Cornelis Speelman (1628-1654), Robert Padtbrugge (1638-1688), Francois Valentijn (1666-1727), van Clotwijk (1752-1755), D.W.Frieijer (1760), dan P.C. Haselaar (1768). ${ }^{7}$

Melihat kenyataan tersebut VOC mencoba untuk melakukan penelitian mendalam dengan menganalisa sistem sosial dan hukum. Untuk bidang hukum,

${ }^{5}$ Soerjono Soekanto, Pengantar Penelitian Hukum, UI-Press, Jakarta, 1986, hlm. 10

${ }^{6}$ Roni Hanitijo Soemitro, Metodologi Penelitian Hukum dan Jurimetri, Ghalia Indonesia, Jakarta, 1990, hlm. 34-35. Lihat juga Sunaryati Hartono, Penelitian Hukum di Indonesia Pada Akhir Abad Ke-20, Alumni, Bandung, 1994, hlm. 139-142.

${ }^{7}$ Soekanto, Meninjau Hukum Adat Indonesia, CV Rajawali, Jakarta, 1981, hlm. 23-24. 
seperti telah disebutkan pada bab terdahulu, VOC hanya melakukan klasifikasi dan kodifikasi. Adapun kebijakan politik hukum saat itu belum terjadi, karena fase ini masih berupa pengamatan, walaupun ada beberapa peraturan, sifatnya hanya sementara dan untuk beberapa kasus tertentu saja.

Setelah perpindahan kekuasaan dari VOC ke tangan Pemerintah kerajaan Belanda tidak ada perubahan yang signifikan. Justru pada saat itu terjadi sebuah kebijakan fenomenal tanam paksa pada masa Den Bosch, kebijakan ini secara sistemik menyengsarakan rakyat pribumi dalam tempo yang panjang. Keadaan ini kemudian dikritik oleh kelompok liberal di Belanda yang kemudian memaksa pemerintah Belanda untuk menghentikan kebijakan tanam paksa. Kemudian secara berangsur-angsur tanam paksa dihentikan hingga secara total diberhentikan pada $1870 .{ }^{8}$

Bersamaan dengan ide penghentian kebijakan tanam paksa, muncul ide pembaharuan pasca amandemen konstitusi 1848 di negeri Belanda. Ide pembaharuan ini mengarah kepada penataan hukum, administrasi, pengelolaan, dan perlakuan kepada rakyat pribumi. Gagasan ini disebut dengan Bewuste rechtspolitike atau politik menata hukum secara sadar, dan darinya lahir sebuah konstitusi Hindia Belanda di 1854. Seiring dengan perubahan Konstitusi 1848 pada akhirnya pemerintah Belanda merubah arah kebijakannya dan mengakomodir kaum liberal dengan kebijakan barunya yang disebut De Bewuste Rechtspolitiek atau politik untuk membina tata hukum kolonial secara sadar, sehingga sistem tanam paksa harus terpaksa berakhir pada $1870 .{ }^{9}$ Kebijakan sadar politik disamping untuk menghentikan kebijakan tanam paksa juga dimaksudkan untuk mengontrol kewenangan raja dan gubernul jenderal berserta aparatnya di tanah jajahan, disamping juga untuk melindungi kepentingan penduduk yang tinggal di Hindia Belanda. Penataan yang dilakukan oleh pemerintah kolonial dalam hal ini terkait dengan penataan ketatanegaraan dan hukum, sehingga konstitusi 1884 sangat erat kaitannya dengan Regeringsreglement 1854 sebagai konstitusi di Hindia Belanda. Dua instrumen hukum ini sangat berpengaruh

${ }^{8}$ Wulan Sondarika, "Dampak Cultuurstelsel (Tanam Paksa) Bagi Masyarakat Indonesia dari Tahun 18301870”, Jurnal Artefak, Vol. 3 No. 1, Maret 2015, hlm. 63.

${ }^{9}$ Soetandyo Wiegnjosoebroto, Dari Hukum Kolonial ke Hukum Nasional, Raja Grafindo, Jakarta, 1995, hlm. 19. 
terhadap perkembangan olitik dan hukum di Hindia Belanda, karena dalam substansinya, terutama Regeringsreglement banyak memuat aturan teknis dan substantif.

Aturan-aturan tersebut mengarah kepada perkembangan dan penataan ketatanegaraan dan administrasi kolonial Hindia Belanda, yaitu mengamanatkan bahwa dalam setiap keputusan dan aturan diperlukan dokumen resmi seperti undang-undang wet dan atau turunannya. Dalam konteks negara modern (welfare state) Regeringsreglement 1854 merupakan ciri pendirian negara hukum atau rule of law, di mana hukum sebagai panglima. Dalam konteks Hindia Belanda dimaksudkan untuk mengefektifkan pendayagunaan hukum untuk melindungi kepentingan-kepentingan penduduk di Hindia Belanda dari kesewenangan pemerintah kolonial. ${ }^{10}$

Perubahan besar yang juga mendapatkan pengaruh dari ide kaum liberal yang berasal dari Konsep kenegaraan Perancis. Konsep tersebut antara lain terdapat dalam Pasal 79, 88, dan 89. Pasal-pasal tersebut menyiratkan konsep trias politica yang menghendaki kekuasaan kehakiman yang bebas kepada hakim (Pasal 79), sedangkan Pasal 88 menghendaki adanya asas legalitas dalam setiap proses pemidanaan, dan Pasal 89 menyebutkan bahwa pemidanaan tidak berarti menghilangkan hak perdatanya. Tiga pasal penting ini menyiratkan sebuah perlindungan hukum terhadap masyarakat dari kesewenangan pemerintah yang cenderung otokratif.

Betapapun gencarnya ide liberalisme di Hindia Belanda, namun internalisasi dan realisasi nilai-nilai tersebut memerlukan proses yang panjang. Hal ini disebabkan adanya benturan pemikiran yang terjadi antara kalangan liberal baik di Belanda maupun Hindia Belanda dengan kalangan birokrat yang cenderung enggan untuk membagi kekuasaan pada lembaga yudisial seperti yang dikehendaki oleh konsep trias politica. Tetapi penataan organisasi dan ketatanegaraan mulai berkembang pada 1860 seiring dengan gencarnya propaganda kaum liberal seperti van Hoevel dan Douwes Dekker. ${ }^{11}$ hlm. 26.

${ }^{10} \mathrm{John}$ Ball, The Struggle for National Law in Indonesia, Faculty of Law University of Sydney, Sydney, 1986,

${ }^{11}$ Kedua tokoh ini sangat gencar dengan tulisan-tulisannya seperti Douwes Dekker dengan Max Havelaar of de koffie-Veilingen Der Nederlandsch Handelmaatschapij. 
Pada prinsipnya kolonialisme Belanda di Hindia adalah sebuah proses dalam membangun tatanan yang lebih baik dengan cara mengenal lebih baik tanah jajahannya. Selain dengan mengenal Islam sebagai salah satu elemen terbesar masyarakat saat itu, Belanda juga menciptakan sebuah tatanan yang satu antara bangsa Eropa dan pribumi. Karenanya Belanda memanfaatkan orangorang pribumi sebagai mitra sekaligus informan yang membantu untuk mengenal jajahannya, yang kemudian bertujuan untuk mencapai perdamaian dan tatanan (rust en orde). Rust en Orde merupakan tujuan dari politik etis dan kebijaksanaan perubahan konstitusi di Belanda maupun Hindia Belanda.

Beragamnya suku, agama, ras dan kebudayaan di Hindia Belanda membuat daerah ini memiliki sistem hukum dan tatanan yang bervariatif pula, oleh karenanya ketika kali pertama VOC datang ke Hindia Belanda untuk menerapkan hegemoni hukumnya mengalami kesulitan. Akhirnya dimulailah sebuah expedisi kodifikasi hukum sebagaimana dijelaskan di atas. Ekspedisi pengkalsifikasian hukum adat terus berlanjut setelah Hindia Belanda berada pada masa penguasaan pemerintah kerajaan Belanda. Dimulai dengan usaha-usaha beberapa tokoh yang mengunjungi Hindia Belanda melali tulisan-tulisan yang tercantum dalam beberapa Majalah seperti, De Oosterling (1835-1837) dan Tijdschrijf Voor Nederland Indie (1838-1902). Majalah-majalah tersebut memuat antara lain tulisan Fillietaz Bousquet tentang peradilan dan kitab-kitab hukum daerah kerajaan Jawa. Kemudian terdapat juga tulisan Mr.J.F.W. van Nes tentang Boedelscheidingen op Java Volgens de kitab Saphihi (klasifikasi hukum masyarakat jawa dalam kitab Saphihi) ${ }^{12}$, dan A Meursinge, dengan judul Handboek van het Mohammadaansche recht in de Maleische Taal (buku kompilasi hukum Muhammad/Islam dalam bahasa melayu). ${ }^{13}$

Selain tokoh yang berkecimpung dalam hukum adat dan antropologi Hindia Belanda, terdapat juga seorang Birokrat bernama Jean Chresien Baud yang menaruh perhatian terhadap usaha pengkodifikasian hukum adat, ia juga yang

12 Keebet von Benda-Beckman, "Anachronism, Agency, and The Contextualization of Adat: Van Vollenhoven Analysis in Light of Struggles over Resources, The Asia Pacific Journal of Anthropology, Vol. 20 No. 5, Oktober 2019, hlm. 397.

${ }^{13}$ Ibid 
mendirikan sekolah ambtenaar (pegawai sipil) di Delft yang dipersiapkan bekerja di Hindia Belanda. ${ }^{14}$

Di antara para tokoh dan pemerhati hukum di tanah Hindia Belanda, paling tidak terdapat tiga orang tokoh yang secara konseptual dan praktis mengusahakan pembentukan sebuah hukum adat, ketiga orang tersebut adalah G.A Wilkens, Liefrinck dan C. Snouck Hurgronje. Wilkens adalah seorang keturunan Manado yang belajar di Belanda, ia memiliki etos yang tinggi dalam mengumpulkan sebuah perbandingan etnografis di sekitar Buru, Gorontalo, Minahasa, Mandailing dan sekitar Batak. Berbeda dengan Wilkens, Liefrinck memiliki metode tersendiri yang berbeda prinsip, Karen ia hanya melakukan observasi terbatas di satu tempat yaitu Bali dan Lombok. Sedangkan yang paling fenomenal dan terkenal baik dari segi karya dan kajian etnografisnya adalah C. Snouck Hurgronje, ia adalah peletak dasar hukum adat dan ahli dalam bidang hukum Islam di Hindia Belanda. Pengalamannya di Mekkah dan keahliannya dalam bidang Indologi membuat ia menjadi tokoh yang fenomenal dalam bidang ini. ${ }^{15}$

Ketika Snouck menjabat sebagai penasehat gubernur Jenderal urusan jajahan, dan tinggal di Indonesia ia banyak menulis karya yang dihasilkan dari perjalanan etnografisnya di Aceh dan Gayo, maka pada 1893-1894 terbitlah buku berjudul De Atjehers dan disusul dengan buku Het Gayoland pada 1903. Dua buku ini merupakan karya fenomenal Snouck karena hanya berdasarkan percakapan semata dengan orang-orang yang berasal dari daerah tersebut. Karena saat itu belum ada ilmuwan yang melakukan metode etnografis seperti Snouck yang dengan sepenuhnya terjun langsung, membaur, dan bahkan merubah namanya seakan-akan adalah orang dari kalangan mereka.

Kelanjutan perkembangan hukum adat setelah tiga tokoh di atas dilanjutkan kemudian oleh C. van Vollenhoven dan muridnya B. Ter Haar. Van Vollenhoven boleh dibilang adalah ilmuwan yang sering disebut dalam literatur hukum adat dan dikatakan sebagai salah satu pelopor utamanya. Van Vollenhoven adalah seorang akademisi Universitas Leiden, ia mulai bersentuhan dengan hukum adat

\footnotetext{
${ }^{14}$ Bushar Muhammad, Asas-asas Hukum Adat, Pradnya Paramitha, Jakarta, 1978, hlm. 94.

${ }^{15}$ Snouck Hurgronje, C.1931. Mecca In the Latter Part of $19^{\text {th }}$ Century (translated by J.H. Monahan). Revised edition, Leiden, E.J. Brill, 2021, hlm. 20.
} 
ketika bekerja di Departemen van Kolonien, meskipun ia hanya beberapa kali ke Hindia Belanda dan juga tidak terlalu lama tinggal disana, tetapi sumbangsihnya terhadap perumusan hukum adat Hindia Belanda begitu besar. ${ }^{16}$

Beberapa teori yang dicetuskan antara lain adalah membagi wilayah hukum adat Indonesia kepada sembilas belas lingkungan hukum adat (adatsrechtkringen), meskipun saat ini pembagian tersebut sudah banyak berubah dan para ilmuwan hukum adat kontemporer tidak memakainya lagi. Gagasan kedua adalah penegasannya terhadap pembedaan hukuman adat dan hukum agama (terutama Islam), dalam hal ini van Vollenhoven menghilangkan kesalahfahaman yang melihat hukum adat adalah hukum agama, termasuk pertentangan terhadap hukum Islam. ${ }^{17}$

Pada perdebatan apakah menerapkan unifikasi atau dualisme, diatas disebutkan bahwa pemerintah akhirnya menerapkan dualisme semu yang artinya tetap memberlakukan beberapa hal tertentu hukum pribumi, termasuk hukum adat yang dibela habis-habisan oleh van Vollenhoven. Dalam hukum adat terdapat juga hukum Islam sebagai bagian dari pranata sosial hukum yang berkembang jauh sebelum bangsa Belanda menginjakkan kaki di Hindia Belanda. para pemikir dan birokrat menaruh perhatian besar terhadap hukum Islam ini karena hal tersebut tidak saja mengatur masalah peribadatan yang sifatnya abstrak dan individual, namun mengatur secara komprehensif kehidupan sosial kemasyarakatan. Oleh demikian itu, hukum Islam menjadi bagian penting dalam pembinaan dan pengembangan hukum adat kala itu. ${ }^{18}$

\section{Penerapan Dualisme Semu}

Seperti diketahui Scholten van Oud Harleem merupakan penggagas ide dualisme hukum, meskipun secara implementatif konsep dualismenya tersebut diarahkan kepada unifikasi secara semu. Gagasan unifikasi secara semu

\footnotetext{
${ }^{16}$ Munir Salim, “Adatrecht Sebagai Bukti Sejarah Perkembangan Hukum Positif di Indonesia”, Jurnal alDaulah, Vol. 4. No. 1, Juni 2015, hlm. 28.

${ }^{17}$ Ikhda Fitria, "Recognizing Adat Law: Problems and Challenges in Modern Law System in Indonesia", The Indonesian Journal of International Clinical Legal Education, Vol. 2. No. 4, Desember 2020, hlm. 3.

${ }^{18}$ Dietrich Jung, "Islam As a Problem: Dutch Religious Politics in East Indies", Review of Religious Research, Vol. 51. No. 3, Maret 2010, hlm. 289
} 
sebenarnya dipengaruhi juga oleh reaksi keras dari para kaum liberal yang menghendaki unifikasi secara tegas.

Sebagai salah satu orang yang berpengaruh di Hindia Belanda, dan kementrian urusan daerah jajahan, Scholten mampu memberikan kontribusi dan pengaruh kepada pemerintah Hindia Belanda dalam urusan hukum. Maka untuk melancarkan gagasannya tersebut bersama timnya, Scholten mengusulkan sebuah rancangan undang-undang besluit yang kemudian disahkan dalam Koninklijk Besluit sebagai Algemeene Bepalingen van Wetgeving. Adapun ketentuan tersebut antara lain:

1. Pasal 5 yang menyatakan bahwa penduduk Hindia Belanda dibedakan kedalam golongan Eropa (beserta mereka yang dipersamakan) dan golongan pribumi (beserta yang dipersamakan)

2. Pasal 9 menyatakan bahwa kitab undang-undang hukum perdata dan kitab undang-undang hukum dagang (yang diberlakukan di Hindia Belanda) hanya akan berlaku untuk golongan Eropa dan mereka yang dipersamakan

3. Kemudian Pasal 11 menyatakan bahwa untuk golongan penduduk pribumi oleh hakim akan diterapkan hukum agama, paranata-pranata, dan kebiasaan orang-orang pribumi itu sendiri, sejauh hukum, pranata dan kebiasaan itu tidak berlawanan dengan asas-asas kepantasan dan keadilan yang diakui umum dan pula apabila terhadap orang-orang pribumi itu telah ditetapkan berlakunya hukum Eropa atau apabila orang pribumi yang bersangkutan telah menundukan diri pada hukum Eropa.

Sekilas pasal tersebut hendak mengetengahkan dan menerapkan dualisme hukum di Hindia Belanda, namun secara tersirat pasal-pasal tersebut mengandung sebuah keinginan untuk secara perlahan-lahan mengukuhkan unifikasi di kemudian hari, meskipun bentuknya adalah dualisme. John Ball telah mengisyaratkan hal yang demikian dalam tulisannya bahwa "the principle of dualism was finally entrenched"19, yang mengartikan bahwa isyarat dualisme telah dikemukakan, paling tidak untuk beberapa dekade kedepan dalam pembangunan politik hukum Hindia Belanda.

${ }^{19}$ Bartholomew, G. "Indonesian Legal History 1602-1848. By John Ball. Sydney: Oughtershaw Press, 1982. Pp. viii, 300. Notes, Bibliography, Index. Journal of Southeast Asian Studies, Vol. 17. No. 1, Agustus 2009, hlm. 181-182. 
Persetujuan kaum liberalis yang hendak mendukung unifikasi diakomodir oleh Scholten dengan kebijakan lain pemerintah Hindia Belanda dengan melancarkan politik vrijwillige onderwepping dan toepasselijk verklaring. Vrijwillige onderwepping dikenal dengan politik penundukan secara sukarela yang dilakukan oleh masyarakat pribumi. Ini dimungkinkan dengan mengarahkan pribumi untuk menggunakan hukum Eropa tatkala berhadapan dengan suatu kasus hukum. Kesadaran atau kesukarelaan pribumi untuk tunduk dengan hukum Eropa pada realitanya juga mendapatkan andil dari pemerintah kolonial. Yaitu dengan menyokong ketidakprofesionalan administrasi pengadilan bagi pribumi. ${ }^{20}$ Asumsi ini dapat dilihat misalnya dalam tata laksana pengadilan agama (priesterraad) yang tidak baik secara adminstratif, maupun esensi pengadilan agama itu sendiri. Pemaknaan priesterraad sangat berbeda dengan pengadilan agama dalam konteks Islam, sehingga kerancuan didapat dalam proses beracara, di samping itu upah para hakim (penghulu atau Qadi) jarang dibayarkan. ${ }^{21}$ Keadaan yang demikian pada akhirnya membuat sebuah pencitraan buruk terhadap pengadilan agama, sehingga pribumi akhirnya memilih untuk menundukan diri terhadap hukum Eropa.

Politik yang berikutnya adalah Toepasselijk Verklaring, politik ini adalah upaya besar-besaran lewat wewenang Gubernur Jenderal untuk menerapkan peraturan perundang-undangan Eropa tertentu kepada pribumi, manakala dipandang perlu. Dua kebijakan ini merupakan langkah handal poliitik hukum HIndia Belanda dalam menyatukan sistem hukum, meskipun secara kenyataan tidak pernah terjadi. Jadi sesungguhnya Pasal 11 dan 75 Regeringsreglement 1854 tidak untuk mempertahankan status quo dualisme hukum, namun dibalik itu terdapat sebuah tujuan utama unifikasi.

Untuk Kebijakan yang dilakukan Gubernur Jenderal melalui Toepasselijk Verklaring misalnya dapat dilihat dalam perundangan yang dibuat dalam konteks peradilan Islam, karena selama ini memang Islam dan hukum Islam menjadi ancaman utama pemerintah Hindia Belanda. Misalnya adalah dalam masalah

${ }^{20}$ Eman Suparman, Hukum Perselisihan (conflictenrecht) Pertautan Sistem Hukum dan Konflik. Kompetensi dalam Pluralisme Hukum Bangsa Pribumi, Kencana, Jakarta, 2018, hlm. 100.

${ }^{21}$ Muhammad Hisyam, Canght Between Three Fires, The Javanese Pangulu Under The Netherlands Colonial Administration 1882-1942, INIS, Jakarta, 2001, hlm. 62. 
perdata perkawinan Islam, sistem perkawinan yang akan diterapkan di Hindia Belanda setelah perubahan konstitusi 1848 dengan mengacu kepada politik unifikasi hukum adalah IBW (Indische Burgelijk wetboek) yang tidak jauh berbeda dengan NBW (Nederland Burgelijk Wetbook). Setelah adanya kebijakan Regeling Reglement maka sistem perkawinan yang berlaku mengacu kepada pembedaan jenis kewarganegaraan. Jenis kewarganegaraan tersebut antara lain: ${ }^{22}$

1. Golongan orang Belanda dan Eropa

2. Golongan Pribumi

3. Golongan Timur Asing, dan Arab

Berdasarkan pembedaan kewarganegaraan tersebut maka kebijakan sistem perkawinan diserahkan kepada masing-masing sistem hukum sesuai dengan golongan perorangan tersebut. Bagi golongan Eropa maka sistem perkawinan yang berlaku ialah sistem yang berlaku di Negeri Belanda dengan ketentuan yang tertuang pada NBW. ${ }^{23}$ Sedangkan bagi orang pribumi maka berlaku beberapa sistem hukum yang sesuai dengan adat dan agamanya, seperti halnya golongan muslim maka berlaku hukum Islam, atupun bagi mereka yang menundukan dirinya kepada hukum adat sesuai dengan suku dan etnis masing-masing. Adapun perkawinan campuran yang dilakukan antar golongan maka berlaku hukum perkawinan campuran (Gemengde Huwelijk).

Pemberlakuan hukum perkawinan dalam penggolongan di atas menegaskan bahwa politik dualisme hukum mulai berlaku, meskipun pada beberapa bagian kebijakan pemerintah kolonial mengisyaratkan sebuah keinginan terhadap unifikasi hukum. Politik Vrijwillige Onderweping dan Toepasselijk Verklaring adalah langkah awal pemerintah kolonial belanda untuk menghapuskan tatanan sistem hukum diluar Hukum Belanda, dengan demikian seluruh rakyat pribumi akan menundukan dirinya sendiri terhadap ketentuan hukum Belanda.

Pada 1882 terbit sebuah Staatblad No. 152 tentang pembentukan sistem peradilan Agama di Jawa dan Madura, melalui peraturan ini dapat diartikan 23.

${ }^{22}$ R.Soepomo, Sistem Hukum di Indonesia Sebelum Perang Dunia II, Pradnya Paramitha, Jakarta, 1997, hlm.

${ }^{23}$ Robert Cribb, "Legal Pluralism and Criminal Law in The Dutch Colonial Order", Indonesia, Cornell University Press, New York, 2010, hlm. 58. 
bahwa pemerintah kolonial Belanda masih memberikan kesempatan kepada golongan muslim untuk memberlakukan sistem hukumnya, terutama dalam hal keluarga. Pembentukan sistem peradilan agama atau yang disebut Priesterraad dibentuk untuk mengadili perkara-perkara perdata yang terkait dengan agama Islam seperti perkawinan, perceraian, harta waris dan wakaf, namun setelah adanya perubahan pada 1 April 1937 kekuasaan peradilan ini mulai dikurangi, terutama pada kasus harta waris dan harta wakaf. Hal tersebut menurut pemerintah kolonial Belanda untuk menghilangkan rasa ketidakadilan pada masyarakat, dan sejak saat itu sengketa-sengketa perdata waris dan wakaf diserahkan kepada pengadilan biasa atau landraad. ${ }^{24}$

Perubahan kebijakan sejak 1937 terhadap peradilan agama memberikan sebuah asumsi yang jelas mengenai kebijakan pemerintah kolonial yang berusaha untuk menaklukan seluruh bentuk sistem hukum kedalam sistem hukum Eropa, meskipun kebijakan unifikasi banyak mendapatkan pertentangan dari berbagai pakar hukum seperti van Vollenhoven dan van der Vinne tetapi pada dasarnya proses penundukan secara bertahap tetap dilakukan, di samping itu van vollenhoven lebih berpihak kepada supremasi hukum adat bagi bangsa pribumi dalam gagasan dualisme hukumnya dan bukan terhadap agama. Dalam berbagai ketentuan seperti yang tertuang dalam Indische Staatsregeling Pasal 134 ayat (2) menyebutkan bahwa perkara perdata hanya dapat diadili dengan cara Islam apabila memenuhi ketentuan jika yang bersengketa adalah orang muslim, dan yang kedua apabila hal tersebut menurut hukum adat harus diajukan kepada pengadilan agama.

Pemberlakuan dualisme sistem hukum yang tidak tegas dalam rangka pencapaian unifikasi hukum yang bertahap telah menjadi kebijakan yang populis saat itu, meskipun sampai Indonesia merdeka keinginan unifikasi tidak tercapai. Namun pada satu sisi proses penguatan pemberlakuan sistem hukum Belanda saat itu telah menciptakan hegemoni hukum yang kuat. Di tengah situasi politik hukum yang seperti ini tentunya menimbulkan permasalahan terhadap eksistensi hukum yang ada di masyarakat, tidak terkecuali hukum keluarga dalam Islam.

${ }^{24}$ Soepomo, Sistem Hukum di Indonesia Sebelum Perang Dunia ke II, Pradnya Paramitha, Jakarta, 1977, hlm. 
Selain itu juga perubahan kebijakan mengenai peradilan agama telah mengkebiri kewenangan hakim agama, sehingga proses hukum terkait dengan perkawinan dan sengketanya tidak diselesaikan sesuai dengan proporsi hukumnya, melainkan diserahkan kepada peradilan umum.

Kajian mengenai kebijakan unifikasi dan dualisme hukum secara bertahap akan menjadi kajian yang menarik dalam rangka mengungkap lebih mendalam politik hukum pemerintah belanda terhadap perkembangan hukum Islam khususnya dalam masalah perkawinan.

Unsur lain yang juga menjadi aspek penting adalah bentuk relasi yang terbangun antara pranata hukum Islam dan hukum adat di dalam mengkompromikan perkara perdata yang berhubungan dengan Islam. Sebagaimana diuraiakan di bagian atas bahwa baik dari kalangan ahli hukum seperti vollenhoven maupun kalangan pemerintah menghendaki setiap perkara perdata Islam diselesaikan secara hukum adat, terkecuali hukum adat tersebut menghendaki penyelesaian secara Islam dalam pengadilan agama (Priesterraad). Dari sini dapat dipahami bahwa terdapat suatu hubungan yang terjalin, sehingga pada perjalanannya akan mempengaruhi pengaturan sistem perkawinan dalam peradilan Islam, baik pada masa kolonial maupun setelah berdirinya Republik Indonesia.

Supremasi hukum adat bagi pribumi yang sekaligus meminggirkan pemberlakuan hukum Islam didasarkan kepada teori receptie yang digagas oleh Snouck Hurgronje dan van Vollenhoven, dan menggantikan teori receptie in complexu yang digagas oleh Lodewijk Willem van den Berg (1845-1927). Teori van den Berg menegaskan bahwa hukum yang dianut oleh pribumi adalah hukum agama yang dianutnya, sehingga hukum adat adalah hukum agama mereka. ${ }^{25}$ Sedangkan pada teori receptie hukum adat adalah hukum rakyat pribumi dan hukum Islam baru berlaku setelah direceptie oleh hukum adat. Berdasarkan teori ini maka akhirnya lahir Staatsblad No. 116 Tahun 1937 yang mereduksi kewenangan pengadilan agama dalam perkara perdata Islam di Hindia Belanda. ${ }^{26}$

${ }_{25}$ Moh.Daud Ali, Hukum Islam, (Pengantar Ilmu Hukum dan Tata Hukum Islam di Indonesia), Raja Grafindo Persada, Jakarta, 2004 hlm. 242

${ }_{26}$ Mahsun Fuad, Hukum Islam Indonesia dari Nalar Parsitipatoris Hingga Emansipatoris, Lkis, Yogyakarta, 2005, hlm. 53. 
Berjalannya teori receptie pada awal abad 20 di Hindia Belanda secara otomatis menundukan sistem hukum Islam ke dalam hukum adat dan dalam lingkup yang luas terhadap hukum Eropa.

Seperti yang sudah diutarakan di muka, terdapat dua kubu dikalangan birokrat maupun ilmuwan antara menyetujui dan tidak menyetujui dualisme hukum. Diantara yang menyetujui adanya dualisme dapat disebutkan yang terkenal di sini ialah C.van Vollenhoven dan Snouck Hurgronje. Van Vollenhoven adalah kalangan ilmuwan dari Leiden yang berusaha keras melestarikan hukum adat dan tentu saja menolak unifikasi.

Adanya unifikasi secara langsung akan mematikan perkembangan hukum adat, ia banyak menganjurkan kepada pemerintah untuk mengadakan pengkajianpengkajian yang mendalam sebelum pemerintah melakukan intervensi-intervensi kedalam tatanan hukum adat, yang didalamnya juga termasuk hukum Islam. Anggapan sebagian orang Belanda bahwa masyarakat pribumi tidak mengenal tatanan hukum dibantah keras oleh van Vollenhoven, dan memaksakan hukum Eropa keapda pribumi bukanlah tindakan tepat dan beradab.27

Pada awalnya respon pemerintah tidak begitu saja mengikuti anjuran van Vollenhoven, justru pada 1914 terjadi kodifikasi Kitab Undang-Undang Hukum Perdata bagi seluruh golongan pribumi, yang tentu saja berlawanan dengan ide dualisme. ${ }^{28}$ Namun dengan cepat van Vollenhoven bereaksi, dan rancangan undang-undang tersebut tidak pernah disahkan.

Setelah RUU 1914 tersebut, pada 1919 adalah Th.B. Pleyte yang memprakarsai undang-undang pertanahan yang menyeragamkan aturan pertanahan di Hindia Belanda ke dalam sistem Eropa. Dengan gigih van Vollenhoven menentang dengan argumen dan tulisan tentang konsep-konsep pertanahan dan hak- hak atasa tanah sebagaimana yang dipraktekan oleh pribumi. ${ }^{29}$ Lagi-lagi rancangan Pleyte ini gugur dan ditarik.

${ }^{27}$ C. van Vollenhoven, Miskeningen van Het Adatrecht, Leiden, Brill, 1909, hlm. 67

${ }_{28}$ Mungkin saja ini adalah politik pemerintah Hindia Belanda (Toepasselijk Verklaring) dengan demikian memaksa kaum pribumi melakukan penundukan dalam bidang perdata ke dalam hukum Eropa. John Ball, Indonesian Law Commentary and Teaching Materials, Jilid I, Faculty of Law Sydney University press, Sydney, 1985, hlm. 36.

${ }^{29}$ C.van Vollenhoven, Indlandsch Grondbezit, Nieuw Rotterdamsche Courant, 3 Desember 1919, hlm. 2 dan C.van Vollenhoven, De Indonesier en zijn Grond, Brill, Leiden, 1932, hlm. 77. 
Rupanya keinginan pemerintah terhadap unifikasi hukum sangatlah kuat, pertentangan antara birokrat yang memiliki latar belakang pemikiran kekuasaan dan hegemoni bertolak belakang dengan pemikiran para ilmuwan yang menghendaki penghormatan terhadap tatanan hukum yang sudah berjalan lama. Demikianlah tidak henti-hentinya pemerintah berusaha, dan terbukti pada 1918 seorang direktur kehakiman di Batavia F.J.H. Cowan dan selanjutnya pada 1923 memperkenalkan rancangan undang-undang hak perdata. Alasan Cowan perlu adanya unifikasi adalah: pertama, bahwa hukum adat tidak tertulis dan tentu saja tidak memiliki kepastian hukum, kedua, apabila bersandar pada hal yang demikian maka sulit untuk seseorang atau suatu hakim untuk memutuskan suatu keadilan. Cowan beralasan unifikasi yang diinginkannya bukanlah karena motif politik atau ekonomi, namun melihat realita bahwa sepanjang pemberlakuan hukum dualisme ternyata masyarakat pribumi lebih memilih pranata hukum barat dibandingkan pranatanya sendiri. ${ }^{30}$

Alasan Cowan memang dapat dibenarkan ketika kebanyakan pribumi memilih pranata peradilan barat Raad van Justitie dibandingkan pranata mereka, katakanlah seperti pranata hukum Islam misalnya dengan priesterraad nya. Namun itu semua tidak terjadi begitu saja dengan alami, karena pemerintah Hindia Belanda turut andil untuk mengalihkan pribumi agar menundukan dirinya pada hukum Eropa. Seperti yang telah disebut di atas bahwa politik Toepasselijk Verklaring dan Vrijwillige Onderwepping adalah kebijakan perlahan untuk unifikasi hukum. Maka kemudian wajar saja apabila Cowan berpendapat bahwa pribumi kemudian memilih pranata Eropa.

Meskipun demikian, lagi-lagi van Vollenhoven dengan sepenuh hati membela keberlakuan hukum adat dan menyatakan bahwa Cowan mengabaikan sebuah tatanan yang hidup, menurutnya bagaimana mungkin merubah suatu tatanan hukum yang hidup dengan sebuah rekayasa unifikasi. Akhirnya rancangan Cowan ditarik, penarikan rancangan Cowan tidak saja berasal dari pertentangan van Vollenhoven, tetapi juga karena kerumitan rancangan tersebut yang berisi 2.200 pasal, dengan pengecualian dan pengecualian yang tidak realistis. ${ }^{31}$

30John Ball John Ball, Indonesian Law Commentary and Teaching Materials, hlm. 39

${ }^{31}$ Ibid 
Gagasan van Vollenhoven dan kubunya, seperti rekannya J. Oppeinheim, semakin berjaya, di 1922 mereka merancang konstitusi Hindia Belanda yang baru, meskipun akhirnya dikesampingkan oleh Gubernur Jenderal S de Graaff. Namun ide dualisme akhirnya kembali berjaya, Ball mengatakan : 1n 1927 van Vollenhoven's effort to preserve adat law from being overwhelmed by western law.....were rewarded by the decision of the Netherlands East Indies Government to abandon its attempts to westernize the private law for the indigenous population by way of legislation". 32

Perlawanan terhadap van Vollenhoven dan eksistensi hukum adat juga datang dari kalangan intelektual, terutama kelompok konservatif. Mereka beralasan bahwa sebaiknya tidak hanya alasan kepentingan pribumi saja yang dikedepankan, namun perlu diperhatikan alasan kepentingan pemerintah kolonial dan lebih besar adalah kepentingan Negara Belanda. Di antara tokoh konservatif tersebut adalah Gerretson dan M.W.F.L Treub, dua tokoh ini memperoleh dana dari para pengusaha minyak di Hindia Belanda untuk mendirikan Fakultas Indologi di Utrecht yang bermaksud menandingi studi Indologi yang ada di Leiden. Tentu saja para ilmuwan Leiden adalah orang-orang yang memiliki simpati terhadap nasib pribumi Hindia Belanda. ${ }^{33}$

Bersama-sama dengan Treub, Gerretson, adalah juga De Louter yang memiliki alasan bahwa pendirian Fakultas Indologi Utrecht, yang disebut sebagai Olie Faculteit (karena pendanaannya diambil dari sumbangan perusahaanperusahaan minya Batavia atau Bataafsche Petroleum Maatschapij), untuk menandingi Fakultas Indologi Leiden yang dianggap telah keluar dari gagasan dan tujuan pemerintah Belanda terhadap Hindia Belanda. Di samping itu juga Leiden dianggap terlalu berlebihan dalam memperjuangkan keberlangsungan hukum adat dan pribumi. ${ }^{34}$

Tokoh yang selanjutnya yang mendukung dualisme hukum adalah Snouck Hurgronje. Ia adalah tokoh yang fenomenal dalam sejarah politik dan hukum Hindia Belanda. Meskipun sepertinya ia mendukung dualisme, tetapi pada dasarnya bertujuan politik untuk sebuah unifikasi.

32Ibid., hlm. 41

${ }^{33}$ Emile Hensen, Gerretson en Indie, Wolters, Noordhoff-Bouwman, Groningen, 1983, hlm. 70.

${ }^{34}$ Ibid., hlm. 59. 
Salah satu ancaman kekukatan pribumi saat itu adalah Islam, Islam sebagai agama mayoritas yang memiliki pranata yang kuat sangat mengancam eksistensi hegemoni pemerintah kolonial. Ini juga yang menjadi alasan perlunya unifikasi untuk meleburkan pranata Islam tersebut. Namun demikian, Snouck beranggapan lain, menaklukan Islam bukan dengan cara kekerasan, termasuk unifikasi hukum yang tidak sesuai. Maka ia memiliki gagasan yang antara lain dengan politik asosiasi dan pendirian institusi yang menopang dan mengakomodir keberlakuan hukum di luar hukum Eropa, salah satunya adalah Het Kantoor Voor Inlandsche Zaken.

\section{Penutup}

Penelitian ini menyimpulkan, pertama, latar belakang lahirnya kebijakan Vrijwillige Onderwepping dan Toepasselijk Verklaring karena diawali perdebatan politik hukum unifikasi dan dualisme. Para birokrat dan ilmuwan berdebat mengenai sistem mana yang akan diterapkan, pada akhirnya pemerintah Hindia Belanda memberlakukan dualisme hukum. Kedua, pengaturan Vrijwillige Onderwepping dan Toepasselijk Verklaring dijalankan dengan menyempitkan kewenangan dan ambiguitas peradilan di luar pranata hukum Eropa, sehingga masyarakat pribumi khususnya dapat menundukan diri kepada hukum Eropa. Pada sisi lain Toepasselijk Verklaring dijalankan dengan peraturan pemerintah atau ordonantie untuk memaksa pribumi menundukkan diri, yang pada akhirnya politik hukum unifikasi adalah tujuan yang ingin dicapai. Kemudian unifikasi hukum di Hindia Belanda tidak pernah tercapai karena Jepang telah lebih dahulu mengambil alih kekuasaan, namun dua kebijakan Vrijwillige Onderwepping dan Toepasselijk Verklaring dalam prosesnya telah mampu secara bertahap menundukan masyarakat kepada hukum Eropa.

\section{Daftar Pustaka}

\section{Buku}

Ali, Moh. Daud, Hukum Islam, (Pengantar Ilmu Hukum dan Tata Hukum Islam di Indonesia), Raja Grafindo Persada, Jakarta, 2004.

Ball, John, The Struggle for National Law in Indonesia, Sydney, Faculty of Law University of Sydney, 1986. 
Ball, John, Indonesian Law Commentary and Teaching Materials, Jilid I, Sydney, Faculty of Law Sydney University press, 1985.

Bushar, Muhammad, Pengantar Hukum Adat, Pradnya Paramitah, Jakarta, 1983 Asas-asas Hukum Adat, Pradnya Paramitha, Jakarta, 1978.

Cribb, Robert, "Legal Pluralism and Criminal Law in The Dutch Colonial Order", Indonesia, Cornell University Press, New York, 2010.

Fuad, Mahsun, Hukum Islam Indonesia dari Nalar Parsitipatoris Hingga Emansipatoris, Yogyakarta, Lkis, 2005.

Furnivall, J.S, Studies in The Social and Economic Development of The Netherlands East Indies IIb, An Introduction to The History of the Netherlands India, 1602-1836, Cambridge University Press, Cambridge, 2010.

Hartono, Sunaryati, Penelitian Hukum di Indonesia Pada Akhir Abad Ke-20, Alumni, Bandung, 1994.

Hensen, Emile, Gerretson en Indie, Groningen, Wolters, Noordhoff-Bouwman, 1983.

Hisyam, Muhammad, Caught Between Three fires, The Javanese Pangulu Under The Netherlands Colonial Administration 1882-1942, INIS, Jakarta, 2001.

Hurgronje, Snouck, C.1931. Mecca In the Latter Part of 19th Century (translated by J.H. Monahan). Revised edition, Leiden, E.J. Brill, 2021.

Soekanto, Soerjono, Meninjau Hukum Adat Indonesia, Rajawali, Jakarta, 1981. Pengantar Penelitian Hukum, UI-Press, Jakarta, 1986.

Soemitro, Roni Hanitijo, Metodologi Penelitian Hukum dan Jurimetri, Ghalia Indonesia, Jakarta, 1990.

Soekanto, Soerjono, Meninjau Hukum Adat Indonesia, CV Rajawali, Jakarta, 1981.

Soepomo, R., Sistem Hukum di Indonesia Sebelum Perang Dunia II, Jakarta, Pradnya Paramitha, 1997.

Suparman, Eman, Hukum Perselisihan (conflictenrecht) Pertautan Sistem Hukum dan Konflik Kompetensi dalam Pluralisme Hukum Bangsa Pribumi, Kencana, Jakarta, 2018.

Vollenhoven, C.Van, Miskeningen van Het Adatrecht Leiden, Brill, 1909. , Indlandsch Grondbezit, Nieuw Rotterdamsche Courant, 3 Desember 1919. ,De Indonesier en zijn Grond, Leiden, Brill, 1932.

Wiegnjosoebroto, Soetandyo, Dari Hukum Kolonial ke Hukum Nasional, Raja Grafindo, Jakarta, 1995.

\section{Jurnal}

Dietrich Jung," Islam As a Problem: Dutch Religious Politics in East Indies", Review of Religious Research, Vol. 51. No. 3, Maret 2010. 
G. Bartholomew, "Indonesian Legal History 1602-1848. By John Ball. Sydney: Oughtershaw Press, 1982. Pp. viii, 300. Notes, Bibliography, Index. Journal of Southeast Asian Studies, Vol. 17. No. 1, Agustus 2009.

Ikhda Fitria, "Recognizing Adat Law: Problems and Challenges in Modern Law System in Indonesia", The Indonesian Journal of International Clinical Legal Education, Vol. 2. No. 4, Desember 2020.

Keebet von Benda-Beckman, "Anachronism, Agency, and The Contextualization of Adat: Van Vollenhoven Analysis in Light of Struggles over Resources, The Asia Pacific Journal of Anthropology, Vol. 20 No. 5, Oktober 2019.

Munir Salim, "Adatrecht Sebagai Bukti Sejarah Perkembangan Hukum Positif di Indonesia", Jurnal al-Daulah, Vol. 4. No. 1, Juni 2015.

Wulan Sondarika, "Dampak Cultuurstelsel (Tanam Paksa) Bagi Masyarakat Indonesia dari Tahun 1830-1870", Jurnal Artefak, Vol.3 No. 1, Maret 2015. 